\title{
Natal tooth in preterm newborn: a case report
}

\author{
Dente natal em recém-nascido pré-termo: relato de caso
}

\author{
Jenifer Garcia ROCHA ${ }^{1}$ \\ Lilian Citty SARMENTO² \\ Ana Maria Martins GOMES² \\ Marly Almeida Saleme do VALLE \\ Elâine Cristina Vargas DADALTO²
}

\begin{abstract}
Low birth weight and prematurity may be associated with delayed dental eruption in the deciduous dentition; notwithstanding this relationship, cases of preterm newborns presenting natal or neonatal teeth have been reported in the literature, although this is a rare occurrence. The objective was to present the report of natal tooth in a preterm newborn, analyzing the uniqueness of this case in contrast to the delayed dental eruption usually observed in association with prematurity. Case report: The newborn infant girl, with a gestational age of 36 weeks and 3 days and birth weight of 2,300 g, was attended to as part of the "Strategies for Oral Health Promotion for Infants" project, linked to the Pediatric Dentistry course at the Federal University of Espírito Santo. The newborn infant was referred by the neonatology and pediatric department of the university hospital as she presented an erupted tooth at birth. Clinical examination, in the region corresponding to the lower central incisors, revealed the presence of an erupted natal tooth and homologous tooth covered in gingival tissue. The periapical radiograph confirmed teeth 71 and 81. Since they were well implanted and did not interfere with breastfeeding, these teeth were retained. The mother was instructed to return if there were ulcerations in the infant's tongue or nipple fissures, with the use of negative reporting regarding the occurrence of alterations up to two months of age. The occurrence of natal tooth teeth is rare, but they may be present in the preterm newborn, despite the association between prematurity and delayed dental eruption in the deciduous dentition.
\end{abstract}

Indexing term: Infant, premature. Natal teeth. Tooth eruption.

\section{RESUMO}

O baixo peso ao nascer e a prematuridade podem estar associados ao atraso na erupção dental na dentição decídua; não obstante esta relação, têm sido relatados na literatura casos de recém-nascidos pré-termo apresentando dentes natais ou neonatais, embora isto seja uma ocorrência rara. O objetivo foi apresentar o relato de dente natal em um recém-nascido pré-termo, analisando a singularidade deste caso em contraponto ao atraso na erupção dental usualmente observado em associação à prematuridade. Relato do caso: O recém-nascido, sexo feminino, com idade gestacional de 36 semanas e 3 dias, peso ao nascimento de $2.300 \mathrm{~g}$, foi atendido no projeto de extensão "Estratégias de Promoção de Saúde Bucal para Bebês" vinculado à disciplina de Odontopediatria da Universidade Federal do Espirito Santo, encaminhado pelo setor de neonatologia e pediatria do hospital universitário por apresentar um dente erupcionado desde o nascimento. Ao exame clínico constatou-se, na região correspondente aos incisivos centrais inferiores, a presença de um dente natal erupcionado e um dente homólogo recoberto pelo tecido gengival. A radiografia periapical evidenciou os elementos $71 \mathrm{e} 81$. Como estavam bem implantados e não interferiam na amamentação, estes dentes foram mantidos. A mãe foi orientada a retornar à clínica caso ocorressem ulcerações na língua do bebê ou fissuras mamilares, havendo relato negativo quanto à ocorrência de alterações, até os dois meses de idade. A ocorrência de dente natal é rara, mas pode estar presente em recém-nascido pré-termo, apesar da associação entre prematuridade e atraso na erupção dental na dentição decídua.

Termos de indexação: Prematuro. Dentes natais. Erupção dentária.

\section{INTRODUCTION}

The first deciduous teeth to erupt in the oral cavity are the lower central incisors at, on average, $8.09 \pm 2.73$ months of age ${ }^{1}$, and is very rare in children under 6 months of age ${ }^{2}$. There are some aspects that may influence the eruption process, linked to premature eruption, in males for example ${ }^{3}$, or related to delayed eruption, such as low birth weight and prematurity ${ }^{4-6}$.
For newborns with a low birth weight (less than $1,500 \mathrm{~g}$ ), or with a gestational age below 30 weeks, a significant delay in eruption of the first deciduous tooth has been demonstrated, when compared with those of low or normal birth weight, or with full-term infants ${ }^{4-5,7}$. On the other hand, when corrected age for prematurity was taken into account, no delay in the eruption process was found in preterm infants, when compared with those born at full term (gestational age of 37 weeks or more) $)^{4,8}$.

${ }^{1}$ Universidade Federal do Espírito Santo, Faculdade de Odontologia. Vitória, ES, Brasil.

2 Universidade Federal do Espírito Santo, Faculdade de Odontologia, Departamento de Clínica Odontológica. Av. Marechal Campos, 1468, 29040-090, Maruípe, Vitória, ES, Brasil. Correspondência para / Correspondence to: ECV DADALTO. E-mail: <elainedadalto@gmail.com>. 
Despite the existence of this relationship between prematurity and the delay in eruption of the first deciduous tooth, cases have been reported in the literature of preterm newborns that have natal or neonatal teeth ${ }^{9-13}$. In a retrospective study of 17,000 children, between 1984 and 2001, the presence of natal teeth was observed in just five newborns, of which two were preterm ${ }^{14}$. A natal tooth is defined as one that is present at birth, while the neonatal tooth is one that erupts in the first month of life, the former being more common ${ }^{15-16}$. A number of factors may influence its presence in the oral cavity, including the unusual superficial position of the tooth germ ${ }^{17}$, infection, poor nutrition ${ }^{18}$, hormonal stimuli, heredity and effects of congenital syphilis ${ }^{15}$.

The aim of the present study is to present a report of a clinical case of natal teeth in preterm newborn, analyzed from the perspective of the uniqueness of this case in contrast to the delay in tooth eruption usually observed when associated with prematurity.

\section{CASE REPORT}

This study used information collected from secondary data from the dental records of a newborn who was referred by the neonatology and pediatric department at the Cassiano Antônio de Moraes University Hospital (HUCAM) for a pediatric dental evaluation due to the presence of a natal tooth. The newborn was seen as part of the "Strategies for Oral Health Promotion for Infants" extension project, linked to the Pediatric Dentistry Course at the Federal University of Espírito Santo. This case report was approved by the research ethics committee at the Health Sciences Center of the Federal University of Espírito Santo (CAAE: 55081116.2.0000.5060).

The medical history showed that the subject was a female, preterm newborn with a birth weight of 2,300 g, gestational age of 36 weeks and 3 days, and an actual age of four days. Her overall health was normal, there being no need to transfer her to a neonatal intensive care unit. The mother stated that the newborn had one tooth in the lower anterior region, that was present at birth.

Upon clinical examination, in the region corresponding to the lower central incisors, the presence of an erupted natal tooth was found as well as a homologous tooth still covered by gum tissue, as shown in Figure 1. The periapical $x$-ray indicated that they related to teeth 71 and 81 , respectively. They were not, therefore, supernumerary teeth (Figure 2). As they belonged to the normal series of the deciduous dentition, they were clinically well implanted and did not interfere with breast-feeding, therefore the teeth were left in situ.

The mother was instructed to return to the clinic if ulcerations on the infant's tongue or nipple fissures occurred due to the presence of these teeth. Directions were provided about hygiene of the teeth and the need for the topical application of fluoride. The case was monitored by means of telephone calls in the first few weeks, with the mother reporting negatively in terms of the occurrence of any alterations. The case was monitored until the infant had reached two months. An examination of the HUCAM patient records, conducted subsequently, confirmed the information supplied by the mother.

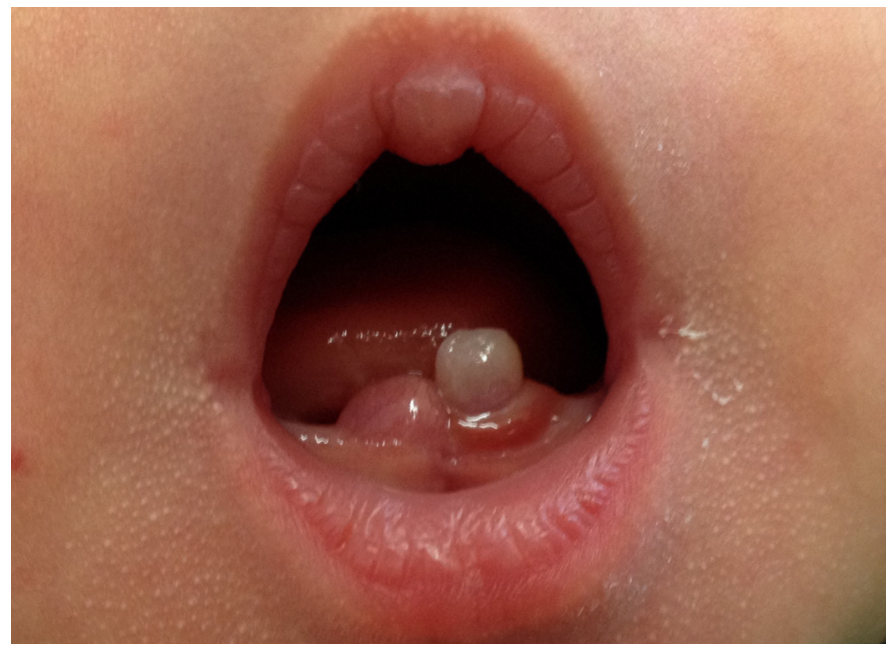

Figure 1. Presence of erupted tooth 71 in preterm newborn.

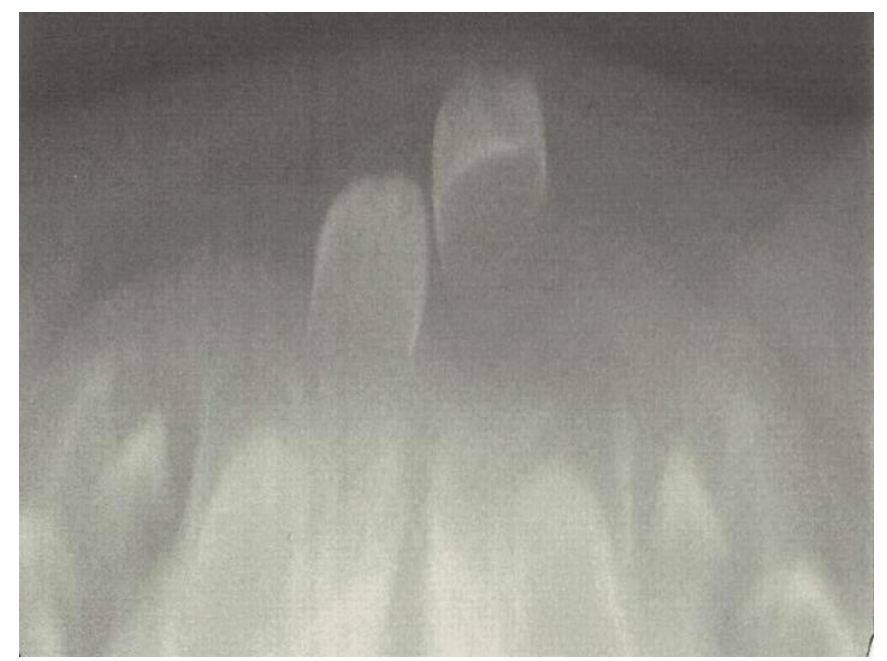

Figure 2. Radiograph showing teeth 71 and 81 in preterm newborn. 


\section{DISCUSSION}

This article presents the report of a case of a natal tooth belonging to the normal series of the deciduous dentition, present since birth, in a four-day-old infant. The occurrence of a natal or neonatal tooth represents an alteration to the chronology of deciduous tooth eruption, considered rare ${ }^{15}$. In most cases, they are small, yellowish in color and with insufficient root development ${ }^{19}$. The etiology is unknown ${ }^{20}$.

Upon clinical examination, no evidence of excessive tooth mobility in the natal tooth was found, despite the $x$-ray having verified that root development was inadequate. The incisal edge was initially rounded (Figure 1), there being no impact on the mother's breastfeeding and no risk of injury to the tongue. Accordingly, the decision was conservative, including just a monitoring of the case and the mother was instructed about the possibility of lesions occurring to the nipple region and the soft tissue of the newborn's oral cavity. This complication is referred to as Riga-Fede syndrome: this is a benign lesion that may present in the form of an ulcer in the ventral region of the tongue, related to the occurrence of trauma ${ }^{21}$. Where a tongue injury is present, light abrasion should be applied in order to smooth and round the sharp edges of the teeth ${ }^{22}$.

The monitoring of the case and the reinforcement of instructions by telephone were important in reassuring the mother in respect of the possibility of immediate treatment should some modification or risk present itself. An extreme treatment would involve the extraction of the natal tooth, which is recommended in the case of a supernumerary tooth, when associated with Riga-Fede syndrome or if is there is excess mobility without bone insertion ${ }^{12,22}$. The concern over excess mobility resulting from insufficient root development stems from the fact that this tooth may constitute a risk to the airways due to the possibility of aspiration ${ }^{13,23}$. However, this risk, in truth, is unlikely, as no reports exist of an actual occurrence of aspiration ${ }^{24}$. Nevertheless, cases of spontaneous exfoliation have been reported ${ }^{9-10}$.

The uniqueness of this case stems from the presence of the natal tooth in a preterm newborn, whose data, as provided by the mother, were corroborated by hospital records. The reporting of natal or neonatal teeth in preterm newborns is very rare, there being very few studies about how frequently this occurs ${ }^{14}$ and with only a few clinical reports appearing in the literature ${ }^{9-13}$ since, in general, dental eruption in children born preterm is delayed in comparison with full-term infants ${ }^{4-6}$.
The delay in the eruption of the first deciduous tooth may be linked to the tribulations of preterm birth, such as the period of orotracheal intubation, the need for prolonged mechanical ventilation or inadequate neonatal feeding ${ }^{7}$. Factors such as low birth weight and prematurity may, in general, have an impact on development, and it could also be possible for tooth development to be impacted such that preterm infants at the moment of birth are not completely developed, thus their chronological age does not correspond to their biological age ${ }^{4}$. Considering the concept of corrected age for prematurity, no delay in eruption was detected in preterm children when compared to those born at full term ${ }^{4,8}$. On the other hand, results were also found indicating that delays in eruption persisted even when the corrected age was used, when comparing the Brazilian average for eruption of the first deciduous tooth $^{6}$

In the report of the case in question, the newborn female had a gestational age of 36 weeks and 3 days and a birth weight of $2,300 \mathrm{~g}$, was in overall good health and did not need to be transferred to a neonatal intensive care unit. This situation is equivalent to a late preterm newborn with low birth weight ${ }^{25}$. In this situation, it is possible that there has not been any delay in dental eruption as the literature states that, for healthy preterm newborns, the first tooth erupts at the normal chronological age ${ }^{7}$. In the same way, birth weight of less than $1,500 \mathrm{~g}$ is mostly related to delay when compared to low birth weight and normal birth weight ${ }^{4}$.

Even when the case refers to late prematurity, the present case reinforces the possibility of a natal tooth occurring in preterm newborns, corroborating the need to include gestational age when analyzing the prevalence of natal and neonatal teeth, so that the prevalence of these teeth associated with prematurity, can be determined. In the cases found in the literature, gestational age corresponded to 24 weeks $^{9}, 28$ weeks $^{13}, 31$ weeks (extreme preterm) ${ }^{11}$ and 33 weeks and four days (very premature) ${ }^{10}$. As far as birth weight is concerned, the low birth weight of the newborn in the present case report was also observed in the literature ${ }^{10}$.

In the cases of natal and neonatal teeth in preterm newborns, found during the bibliographic research, hypermobility of the tooth was a constant, with the occurrence of spontaneous exfoliation ${ }^{9}$, extraction ${ }^{11-13}$, and one case in which one of the teeth was extracted while the other presented with spontaneous exfoliation ${ }^{10}$, different from the case in this article as it was possible to perform conservative treatment, by retaining the tooth. In cases 
where extraction is indicated before the infant reaches 10 days, it is prudent to evaluate, in conjunction with the pediatrician, the need for prophylactic administration of vitamin $\mathrm{K}$ to prevent hemorrhaging caused by hypoprothrombinemia ${ }^{12,26}$.

The referral of the newborn girl by the hospital's neonatology and pediatrics unit demonstrated the importance of interaction between pediatricians and pediatric dentists, with the handling of cases of natal and neonatal teeth, for early diagnosis and an integrated approach with a view to health promotion. The pediatrician, as the health professional involved in the initial contact with the newborn, has an important role in the referral of these $\operatorname{cases}^{27}$.

\section{CONCLUSION}

The occurrence of natal teeth is rare but may occur in preterm newborns despite the connection between

\section{References}

1. Folayan M, Owotade F, Adejuyigbe E, Sen S, Lawal B, Ndukwe $K$. The timing of eruption of the primary dentition in Nigerian children. Am J Physical Anthropol. 2007;134(4):443-8. doi: 10.1002/ajpa.20635

2. Oziegbe EO, Adekoya-Sofowora C, Folayan MO, Esan TA, Owotade FJ. Relationship between socio-demographic and anthropometric variables and number of erupted primary teeth in suburban Nigerian children. Matern Child Nutr. 2009;5(1):8692. doi: 10.1111/j.1740-8709.2008.00

3. Patrianova $M E$, Kroll $C D$, Bérzin F. Sequência e cronologia de erupção dos dentes decíduos em crianças do município de Itajaí (SC). Rev Sul-Bras Odontol. 2010;7(4):406-13.

4. Ramos SRP, Gugisch RC, Fraiz FC. The influence of gestational age and birth weight of the newborn on tooth eruption. J Appl Oral Sci. 2006;14(4):228-32

5. Rezende KMPC, Zollner MSAC, Santos MRN. Avaliação da erupção dentária decídua em bebês considerados de risco. Pesq Bras Odontoped Clin Integr. 2010;10(1):61-5. doi: 10.4034/151 9.0501.2010.0101.0010

6. Neto PGF, Falcão MC. Cronologia de erupção dos primeiros dentes decíduos em crianças nascidas prematuras com peso inferior a 1500g. Rev Paul Pediatr. 2014;32(1):17-23.

7. Viscardi RM, Romberg E, Abrams RG. Delayed primary tooth eruption in premature infants: relationship to neonatal factors. Pediatr Dent. 1994;16(1):23-8.

8. Paulsson $L$, Bondemark $L$, Söderfeldt B. A systematic review of the consequences of premature birth on palatal morphology, dental occlusion, tooth-crown dimensions, and tooth maturity and eruption. Angle Orthod. 2004;74(2):269-79. prematurity and delay in dental eruption in the deciduous dentition.

The interaction of specialists in neonatology, pediatrics and pediatric dentistry, in the evaluation and diagnosis of natal and neonatal teeth, was found to be important for a quick response through clinical and radiographic examinations, enabling a conservative approach to tooth retention.

The directions provided to the mother empowered the family to deal with this altered pattern of tooth eruption, particularly in a child with low birth weight, leading to successful breastfeeding.

\section{Collaborators}

All authors participated in the decisions on the care of the newborn, participated in the drafting of the article and approved the final version of this manuscript.

9. Sureshkumar R, McAulay AH. Natal and neonatal teeth. Arch Dis Child Fetal Neonatal. 2002;87:F227.

10. Dyment $\mathrm{H}$, Anderson R, Humphrey J, Chase I. Residual neonatal teeth: a case report. J Can Dent Assoc. 2005;71(6):394-97.

11. Cizmeci MN, Kanburoglu MK, Uzun FK, Tatli MM. Neonatal tooth in a preterm infant. Eur J Pediatr. 2013;172(2):279. doi: 10.1007/s00431-012-1912-4

12. Verma KG, Verma $P$, Singh $N$, Sachdeva SK. Natal tooth in a seven months premature male child: a rare case report. Arch Intern Surg. 2013;3:182-84. doi: 10.4103/2278-9596.122982.

13. Martins AA, Ferraz C, Vaz R. Um caso raro de dentes neonatais. Acta Med. 2015;28(6):773-5.

14. Khatib KE, Abouchadi A, Nassih M, Rzin A, Jidal B, Danino A, et al. Dents natales: à propos de cinq cas. Rev Stomatol Chir Maxillofac. 2005;106:325-7.

15. Massler M, Savara BS. Natal and Neonatal Teeth a Review of twenty-four cases reported in the literature. J Pediatrics. 1950;36(3):349-59.

16. Cunha RF, Boer FAC, Torriani DD, Frossard WTG. Natal and neonatal teeth: review of the literature. Pediatr Dent. 2001;23(2):158-62.

17. Boyd JD, Miles AEW. An erupted tooth in a cyclops foetus. $\mathrm{Br}$ Dent J. 1951;91(7):173-81.

18. Leung AKC. Natal teeth. Am J Dis Child. 1986;140:249-51.

19. Zhu J, King D. Natal and neonatal teeth. ASDC J Dent Child 1995;62(2):123-8.

20. Leung AKC, Robson WLM. Natal teeth: a review. J Natl Med Assoc. 2006;98(2):226-8. 
21. Calistru AM, Lisboa C, Bettencourt H, Azevedo F. Case for diagnosis. Riga-Fede disease. 2012;87(5):791-2.

22. Nogueira JSE, Filho AJGG, Moda LB, Oliveira RP. Doença de RigaFede: relato de dois casos - um conservador e outro radical. Rev Assoc Paul Cir Dent. 2014;68(2):100-4

23. Welbury RR, Duggal MS, Hosey MT. Paediatric dentistry. 3 ed. Oxford: Oxford University Press; 2005.

24. Ooshima T, Mihara J, Saito T, Sobue S. Eruption of tooth-like structure following the exfoliation of natal tooth: report of case. ASDC J Dent Child. 1986;53(4):275-8.

25. Ibidi SM, Cardoso LEMB. Classificação do recém-nascido: cuidados com o RN PIG e RN GIG. In: Vaz FAC, Diniz EMA, Ceccon MEJR, Krels VLJ. Neonatologia. Barueri: Manole; 2011. p. 3-6.
26. Anegundi RT, Sudha $P$, Kaveri $H$, Sadanand K. Natal and neonatal teeth: A report of four cases. J Indian Sot Pedo Prev Dent. 2002;20(3):86-92.

27. Diniz MB, Gondim JO, Pansani CA, Lima FCBA. A importância da interação entre odontopediatrias e pediatrias no manejo de dentes natais e neonatais. Rev Paul Pediatr. 2008;26(1):64-69.

Received on: 16/10/2016

Final version resubmitted on: 10/2/2017

Approved on: 27/2/2017 